Acta vet. scand. 1988, 29, 139-141.

Brief Communication

\title{
Cromoglycate Induces a Rebound Effect on Blood/Milk Permeability in Subclinical Mastitis
}

Chronic subclinical mastitis represents a vicious cycle of constant tissue irritation by bacteria and inflammatory response of the host. Antibiotics have proven relatively inefficient in eliminating chronic mastitic infections. The use of anti-inflammatory agents in mastitis is controversial. Theoretically, the inflammation should not be suppressed as this is a host defence mechanism of the body. However, because it is uncertain whether the infection or chronic inflammation causes more harm to the tissue, there have been efforts to use anti-inflammatory agents such as glucocorticoids and antipyretic analgetics. The problem is that there is insufficient evidence as to which inflammatory mediators (histamine, kinins, prostaglandins, leukotrienes, PAF, interleukin-1 etc.) alone or in combination are important in mastitis.

Sodium cromoglycate has been used to prevent attacks of bronchial hyperreactivity and allergic rhinitis in man and horse. The compound previously considered to be predominantly a mast-cell stabilizing agent, is effective profylactically in inhibition of early and late phase asthmatic reaction. Recently, it has been suggested that cromoglycate may also exhibit other mechanisms of antiallergic action unrelated to mast cell activation (Kuriyama et al. 1986).

Macrophages and mast cells are probably the most important cells regulating the local inflammatory responses within the bovine udder (Craven \& Williams 1985). Mast cells are usually found alongside blood vessels in the connective tissue, although they have also been reported to exist subepithelially along the lower parts of the milk ducts (Nickerson \& Heald 1982). Histamine is stored primarily in mast cell granules. Milk from cows with mastitis shows increased concentrations of histamine (Cecil et al. 1965). Infusion of the bovine mammary gland with histamine results in a condition resembling acute mastitis with oedema and increase of blood protein levels in milk (Jain et al. 1972). It is evident that mast cells can also elicit and regulate late phase inflammatory reactions such as infiltration with eosinophils, neutrophils and fibrin as well as stimulate macrophages and fibroblasts (Kaliner \& Lemanske 1984). In experimental mastitis, histamine concentration in milk was found to increase after the early acute reaction and thus histamine was suggested to have a role in tissue repair (Zarkower \& Norcross 1966). This pilot study was carried out to study whether sodium cromoglycate would alter the course of inflammation within the mammary gland. Quarters of 11 Finnish Ayrshire cows at their midlactation were monitored for mastitis for 1 month using conventional bacteriology, somatic cell counting (SCC), as well as $\mathrm{N}$-acetyl- $\beta$-D-glucosaminidase (NAGase) and antitrypsin (ATR) activity as inflammatory markers (Mattila et al. 1986). One quarter of each cow, subclinically infec- 
ted by staphylococci or streptococci, were selected for the experiment. Sodium cromoglycate inhalation solution (Lomudal 10 $\mathrm{mg} / \mathrm{ml}$, Fisons Pharmaceuticals, analogous to cromolyn sodium, USP) was infused after milking into the affected quarters in a dose of 40-80 mg/quarter (a volume of 2-4 ml). In each cow, a quarter with the lowest values of inflammatory parameters served as an untreated control. The quarters were monitored for infection and inflammation with the above techniques during subsequent milkings for 1 week.

Infusion of sodium cromoglycate into the affected quarters neither had any effect on the infective status of the glands nor did suppress the inflammatory condition. However, a clear short-term increase in milk antitrypsin was evident 48-72 $\mathrm{h}$ after intrammary infusion of the dose in 7 of the 11 mastitic quarters (Fig. 1). A slight reaction in NAGase was seen concomitantly with the ATR peak in 3 quarters but SCC did not show apparent response in any of the infused quar-

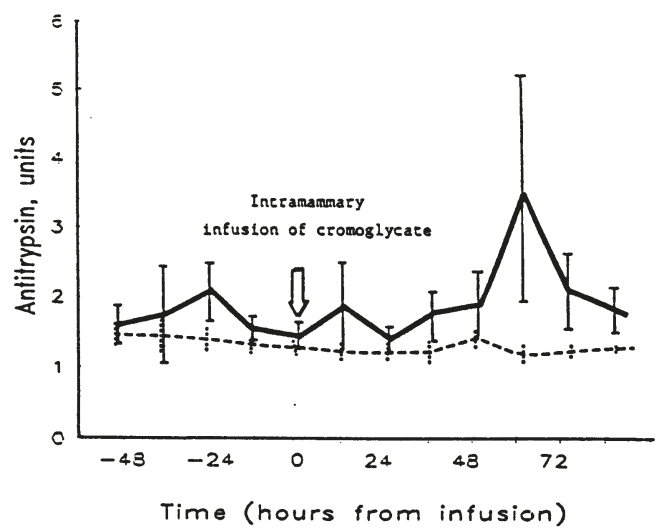

Figure 1. Effect of intracisternally administred sodium cromoglycate on milk antitrypsin activity in subclinical mastitis. Solid line = treated quarters, dotted line $=$ untreated control quarters. Each point is the mean \pm s.e. $(n=11)$. ters. The increase in permeability after a few days as indicated by increased antitrypsin can be interpreted as follows: the local suppression of the regulatory cells (mast cells) resulted in a rebound activation of these cells including histamine release. The conclusion of the present study is that cromoglycate did not positively affect the course of chronic mastitis. It has to be emphasized, that the drug is poorly absorbed by the udder due to its low lipid solubility, and the concentration in the tissues is probably low.

\section{S. Pyörälä, T. Mattila and M. Sandholm.}

The Department of Clinical Veterinary Medicine, College of Veterinary Medicine, Helsinki, Finland.

\section{References}

Cecil H C, Bitman J, Wood J R: Changes in milk glycogen during mastitis. J. Dairy Sci. 1965, 48, 1607-1611.

Craven N, Williams $M R$ : Deferences of the bovine mammary gland against infection and prospects for their enhancement. Vet. Immunol. Immunopathol. 1985, 10, 71-127.

Jain N C, Schalm $O W$, Carroll $E J$, Lasmanis J: Leucocytes and tissue factors in the pathogenesis of bovine mastitis. Amer. J. vet. Res. 1972, 33, 1137-1145.

Kaliner $M$, Lemanske $R$ : Inflammatory responses to mast cell granules. Fed. Proc. 1984, 43, 28462851.

Kuriyama K, Yoshiyuki H, Nagatahira R, Okuda T, Saito K, Kiyoshi I: An antiallergic activity of disodium cromoglycate unrelated to mast cell activation. Agents and Actions 1986, 18, 473-478.

Mattila T, Syväjärvi J, Jensen NE, Sandholm M: NAcetyl- $\beta$-D-glucosaminidase and antitrypsin in subclinically infected quartermilk samples: Effect of bacteria and hemolysins, lactation stage, and lactation number. Amer. J. vet. Res. 1986, 47, 139-142. 
Nickerson C S, Heald C W: Cells in local reaction to experimental Staphylococcus aureus infection in bovine mammary gland. J. Dairy Sci., 1981, 65, 105-116.

(Received February 2, 1988).

Reprints may be requested from: Satu Pyörälä, SF-04840 Hautjärvi, Finland.
Zarkower A, Norcross N L: Aspects of hypersensitivity in Streptococcus agalactiae infection in the cow. Cornell Vet. 1966, 156, 566-587.

Reprints may be requested from: Satu Pyorala, SF-04840 Hautjarvi, Finland. 
